\title{
The Role of Centers of Teaching and Learning in Supporting Higher Education Students Learning
}

\author{
George Asimakopoulos \\ University of Patras
}

\author{
Thanassis Karalis \\ University of Patras
}

\author{
Katerina Kedraka \\ Democritus University of Thrace
}

\begin{abstract}
This paper studies the Centers for Teaching and Learning (CTL) of the 100 top Universities in the world and investigates their role and services. The vast majority of these Centers is located in educational institutions of the US, the UK, Australia and Canada. CTL services cover many areas and target several portions of the university population. They try to meet contemporary requirements and aim to enhance teaching, learning and research processes. They usually do not restrict their fields of activities to teaching staff (faculty members, post-graduate students), extending them to students and research staff as well. Literature review indicates that the main areas in which students face difficulties and need help are: the pace of study, academic and study skills, some psychological factors, active participation in learning and self-directed learning. As a result, to help learning and enhance academic success, CTLs try to offer activities that boost academic skills (studying strategies and productivity enhancement), acceptable academic behavior, digital skills and general support and guidance.
\end{abstract}

Keywords: centers for teaching and learning, services, university, support

\section{INTRODUCTION}

Continuous change in contemporary societies forces universities to discover efficient methods so as to be flexible and constantly updated (Raikou \& Karalis, 2011). Kedraka \& Rotidi (2017) point out the importance of higher education pedagogy. They consider it a multidimensional process which relates to specific teaching practices and approaches. They claim that training and support within the university environment can promote active student learning. Moreover, modern learning theories alongside the use of technology-enhanced pedagogical tools, call for more active student learning and a shift in the role of modern higher education institutes (Wells \& Edwards, 2013).

Centers for Teaching and Learning (CTL) are relatively recent support structures, operating within academic institutions. They first appeared in the second half of the 20th century but they grew remarkably just in the last two decades. Given the particularity and variation among academic institutions around the 
world, there are significant differences both in terms of mission, functions, organizational structure (Hurtado \& Sork, 2015), and in terms of the name used for these: usually we find them under the name Center for Teaching and Learning (CTL) or Centre for Enhancement of Teaching and Learning (CETL). Sometimes terms such as "excellence", "innovation", "development", "promotion", "advancement" and "support" are also included.

According to Hurtado and Sork (op. Cit.), The Center for Teaching and Learning (CTL) at the University of Michigan was the first to be established in the United States in 1962. Over the last two decades, hundreds of tertiary education institutions in the United States have established such centers, responding to a similar national call, to support and promote remedial change in institutions. According to McDowell et. al. (2007), the corresponding offices in the United Kingdom (Centres for Excellence in Teaching \& Learning - CETL) emerged from a "Government White Paper" entitled "The Future of Higher Education", published in 2003, which recognized that effective teaching and learning are essential elements for promoting excellence and opportunities in Higher Education. The Centres for Excellence in Teaching and Learning (CETLs) were proposed as a way for teaching and learning practices to be recognized, rewarded and good practice disseminated. In fact, successful CTLs would receive significant funding to enhance the learning experience of their students.

In this paper, we first present the categories of academic staff that CTLs target. Then we present the service categories they offer. Then, based on a review of the relevant literature, we list the basic learning needs of students, which are supported by CTLs. Finally, we gather the services offered by the CTL of the 100 top universities that meet the academic needs of students.

\section{OUR STUDY OF CTLS}

We based this study on "The World's Top 100 Universities, 2020" and the "QS World University Rankings 2020" and we examined the orientation and character of CTLs. From the lists we included the first 100 institutions with a CTL or similar support structure. We found that the vast majority of institutions with CTLs are in USA (35\%) and UK (55\%), other European countries (16\%) along with Australia (9\%) and Canada (5\%) follow, while Japan and New Zealand (6\%) and other Asian countries (9\%) come last. CTLs mainly support faculty members in improving their teaching. By offering help and support to teaching staff, they aim to enhance students' learning (Fry et al., 2009). This kind of academic support derives from a student-centered approach to both teaching methods and teaching environment (Klemenčič et al., 2020). But as we can see in Table 1, almost half of the CTLs include students to their support services. That is a direct support approach.

$24 \%$ of CTLs have special programs/courses for Teaching Assistants, while $29 \%$ offer support to postgraduate and $9 \%$ to post-doctoral students. They support and train these staff categories in order to obtain student learning enhancement. Apart from teaching support, research support is important for universities. So $15 \%$ of CTLs offer support programs for researchers in the fields relative to the teaching enhancement. While all CTLs must be in co-operation with other stuctures within the academic environment, $7 \%$ of them officialy support Schools, Sections or Teaching Units offering support during curriculum and program design, teaching material or teaching spaces choices.

TABLE 1

UNIVERSITY POPULATION SUPPORTED BY CTLS

\begin{tabular}{|l|c|}
\hline \multicolumn{1}{|c|}{ Supported categories } & No of CTLs (total 100) \\
\hline Faculty members & 99 \\
\hline Students & 45 \\
\hline Researchers & 15 \\
\hline Post-graduate students & 29 \\
\hline Post-docs & 9 \\
\hline
\end{tabular}




\begin{tabular}{|l|c|}
\hline \multicolumn{1}{|c|}{ Supported categories } & No of CTLs (total 100) \\
\hline Schools, Sections, Teaching Units & 7 \\
\hline Teaching Assistants & 24 \\
\hline Other staff & 9 \\
\hline
\end{tabular}

\section{SERVICES PROVIDED}

The services provided by CTLs are very widespread as they reflect the differences in the institutions character, organization and countries/cultures. In Table 2 we tried to capture the main thematic areas, which the CTL services refer to.

More than half of the CTLs (52\%) offer counseling support, very often personalized and tailored to the needs of the teaching staff that request them. A significant number of CTLs (40\%) offer structured learning programs/courses/lessons for both teaching staff and students on a variety of topics. Also $44 \%$ offer labs/seminars/institutes, while the same percentage (44\%) has teaching/learning resources-materials and/or libraries to support staff and students. On the other hand, only a 1/5 of CTL (21\%) organizes events such as conferences or symposiums.

CTLs that enhance innovation and teaching excellence or offer corresponding teaching excellence awards reach the remarkable percentage of $44 \%$. Similar is the number $(42 \%)$ of CTLs that offer or promote scholarships or funding for teaching development, while enhancing professional development of teaching staff $(16 \%)$.

Following the developments in digital technologies, more than $1 / 3$ of the Centers $(37 \%)$ offer ICT/educational technology training and mobile learning training. Almost 1/4 (23\%) support the use of digital support platforms (Moodle, Zoom, Canvas, LMS etc) that have been developed or adopted by the respective educational institutions. In this context, several CTLs support online/distance teaching/learning or flipped classroom (Klemenčič et al., 2020).

TABLE 2

SERVICES PROVIDED BY CTLS

\begin{tabular}{|l|c|}
\hline \multicolumn{1}{|c|}{ Service / thematic area } & No of CTLs (total 100) \\
\hline Consultation services & 52 \\
\hline Training programs/courses/lessons & 40 \\
\hline Labs/seminars/institutes & 44 \\
\hline Teaching/learning resources/materials & 44 \\
\hline Events & 21 \\
\hline Innovation/ teaching excellence /awards & 44 \\
\hline Scholarships/funding & 42 \\
\hline Professional development & 16 \\
\hline ICT/educational technology training & 37 \\
\hline Digital support platforms & 23 \\
\hline Online/distance teaching/learning & 23 \\
\hline Learning communities/groups/networks & 36 \\
\hline Research support & 20 \\
\hline Course design & 32 \\
\hline Teaching strategies /enhancement & 18 \\
\hline Course observation/analysis & 18 \\
\hline Curriculum/program design & 11 \\
\hline Assessment and feedback & 42 \\
\hline Inclusive education & 17 \\
\hline
\end{tabular}




\begin{tabular}{|l|c|}
\hline \multicolumn{1}{|c|}{ Service / thematic area } & No of CTLs (total 100) \\
\hline Studying strategies / academic success & 22 \\
\hline Academic writing & 12 \\
\hline
\end{tabular}

In order to exchange knowledge and experiences, $36 \%$ of the Centers coordinate or encourage learning communities, exchange groups or special networks. At the same time, $20 \%$ offer support to researchers (undergraduate students to post-docs), as the universities themselves rely on research to produce knowledge.

Regarding the specific thematic areas, in which the Centers offer support, we could single out lesson design (32\%), effective teaching strategies / teaching enhancement $(18 \%)$, lesson observation/analysis $(18 \%)$, curriculum/program design (11\%), assessment and feedback (42\%) and inclusive education (17\%). For students, in particular, support is offered in areas such as studying strategies / academic success and time management (22\%) and especially academic writing (12\%) (op. Cit).

\section{LITERATURE REVIEW}

Regarding the academic problems students face in a university environment, our literature review highlighted, among others:

\section{To a Large Extent Students, Especially Freshmen, Seem to Have Problems in Pacing Their Study}

The Trueman \& Hartley (1996) research sought to correlate students' time management skills with their academic performance. The analysis showed a positive correlation between performance in time management and academic performance, which was more often observed in older, more mature students. Time management has also been found to be a critical skill in terms of student success.

The study of Giovazolias, Leontopoulou \& Triliva (2010) investigated the counseling needs of students in two Greek Universities, their knowledge about the operation of a university counseling center as well as their attitudes towards seeking help from such a center. The main problems reported by the students were related to personal relationships and emotional difficulties, life planning, decision making and time management.

The research of Hassanbeigi et al. (2011) aimed to investigate the relationship between different study skills and students' academic performance. The study skills that were explored and for which a high positive correlation was found with the students' performance, were: 1. time management and procrastination, 2. concentration and memory, 3 . study aids and note-taking, 4. examination and stress management strategies, 5. organization and processing of information, 6. motivation and behavior and 7. reading and locating the main idea.

The Brooker, Brooker \& Lawrence (2017) survey was conducted on freshmen at the University of Melbourne in 2013 and 2014 and covered their perceptions of 11 commonly reported difficulties. The main ones were time management, workload and the expectations of others (such as family, institution, etc.), which was found to be in line with other larger-scale research aimed at freshmen. The peculiarity of this research was the investigation and the evaluation of a larger number of difficulties.

Time management has also emerged from the research of Blankstein, Wolf-Eisenberg \& Braddlee (2019) as one of the most pressing challenges for students not directly related to the curriculum. The research was conducted in the framework of the CCLASS project (Community College Libraries and Academic Support for Student Success) in 2018 in US college. It examined how the students themselves perceive success, what challenges they face and what services can be developed to support the students effectively in achieving success.

The Adebayo (2015) research examined the impact that time management has on the academic performance of undergraduate students in Nigeria. Data analysis showed a significant correlation between time management, procrastination and students' priorities with their academic performance.

The purpose of the Dalli (2014) research was to investigate the interdependence between students' time management skills (different faculties at a Turkish University), academic life satisfaction and levels of 
academic success. According to the findings, a statistically significant positive correlation was recorded between students' time management skills, academic life satisfaction and academic achievement levels. Research shows that students can become more efficient at managing their time as long as they adopt the right habits.

\section{Many Students Need Support in Areas Such as Academic/Study Skills}

The Dietsche's (2012) study sought to describe the use of support services by Canadian college students and the factors that influence it. The students mostly mentioned math skills, study skills and effective examination skills as their most important shortcomings. At the same time, significant percentages of students indicated that they could clearly benefit from additional support in areas such as study skills, exam performance and professional guidance. They also reported significant improvement in writing, reading and language comprehension skills as a result of the support they received.

The Malek's study (2014) explored three common problems faced by students, according to university professors: tardiness, procrastination, and plagiarism. These problems are related to time management and study skills and can lead, according to this study, to poor performance or failure.

Naqvi et al. (2018) conducted a small-scale survey at a private higher education institution in Oman to assess the level of study skills they considered undergraduate students to possess, and to investigate possible correlations with academic performance and demographic characteristics. Among other things, the research found that most students did not have sufficient basic study skills, such as critical and creative thinking, effective time management and exam preparation.

Griffin et al. (2012) attempted to answer the question of whether learning and study skills affect academic performance. Their research was conducted on first-year undergraduate students at a public university in the USA. The analysis showed a clear positive correlation between the students' average performance and the eight of the ten scales of the questionnaire used: 1. behavior and interest, 2 . concentration and attention, 3. information processing, 4. motivation, 5. self-control, 6. learning aids, 7. time management and 8 . control/preparation strategies.

Sahin (2009) analyzed the changes associated with the 21 st century both cognitively and didactically. Since, according to the author, information and technology are important for modern society, new learning skills follow the needs of society. Therefore in recent years educators at every level have focused on improving high-level mental skills and technological literacy. Thus, in order to acquire the skills of the $21 \mathrm{st}$ century, it is necessary to pursue, among other things: emphasis on learning skills, utilization of modern tools for the cultivation of learning skills, teaching and learning in a modern context, use of modern assessment methods, which can evaluate the skills of the 21 st century.

The research of Atik \& Yalçin (2010) examined the greater and less important counseling needs of undergraduate students at a university in Ankara. In terms of academic issues, the research identified high needs of students in areas such as exam stress, poor study habits, fear of failure, coping with procrastination and academic stress.

The primary goal of Stelnicki, Nordstokke \& Saklofske (2015) research was to understand how students themselves describe the personal characteristics and external factors that help or prevent them from achieving their goals while studying at university. The research was conducted on freshmen at a major university in Canada and among the most important factors in achieving academic goals was future orientation, perseverance and strong executive functioning skills. Stress, poor academic skills and distraction were the main factors that prevented participating students from achieving their goals.

The Tanga \& Maphosa (2018) research explored the barriers faced by undergraduate students at a South African University. The results highlighted a large number of challenges freshmen face. These include academic writing, the proper rendering of bibliographic reports, plagiarism, the use of the right language and the difficulty of using new technologies.

Research by Dagdag, Cuizon \& Bete (2019) examined the problems experienced by students of a higher education institution in the Philippines in the hope of outlining activities that meet their needs and academic achievements. The results of the research showed in the 4th place in order of importance the academic problems, connecting them with the academic performance of the students. 


\section{Some Psychosocial Factors Are Crucial for Students' Success}

Cooke et al. (2006) attempted to sketch the mental health of students during their first year at university. Their research (part of the wider UNIversity Quality of Life and Learning survey conducted at a UK university) also examined how students manage their mental health in relation to the University's counseling services. The results showed that students experience more stress at the beginning of their studies than before. Overall it seemed that the first year is a period of comparatively increased stress for many students. However, it made an impression that only $1 / 3$ of the most psychologically vulnerable students reported that they resorted to counseling services.

The research of Krumrei-Mancuso et al. (2013) examined the role of six psychosocial factors in the academic performance of students at a US public university during the academic year 2008-2009. The purpose of the research was to identify factors that are critical to student success. The analysis of the data showed that academic self-efficacy, time management, involvement with the activities of the institution and emotional satisfaction from academic life are psychosocial factors related to student performance. Therefore students who do not have stress and time management skills may be more prone to procrastination or avoidance of activities. These students are likely to benefit most from interventions that focus on stress management and boosting confidence in academic requirements.

\section{Active Participation in Learning and Self-Directed Learning Are Related to Students' Academic Performance}

The Fook \& Sidhu (2015) research explored the learning challenges faced by students at a University in the USA. Data analysis highlighted eight major learning challenges, including cognitive challenges, active participation in learning and time management.

The research of Tekkol \& Demirel (2018) aimed at highlighting self-directed learning skills and the relationship they have with the willingness of students to actively participate in studies. Data analysis found, among other things, that self-directed learning skills are indeed related to students' academic performance and participation.

\section{SERVICES OFFERED TO STUDENTS BY CTLS}

Trying to meet the needs of students, CTLs provide corresponding services. Searching for data from the 100 top universities, we found the following services, which they offer to their students (see Table 3).

TABLE 3

STUDENT SERVICES OFFERED BY CTLS

\begin{tabular}{|l|l|}
\hline Skill categories & Services for students \\
\hline & effective study strategies \\
& personal time management \\
& problem solving strategies \\
& writing assignments \\
critical thinking & argument developing \\
Academic skills & studying for exams \\
& living in the university \\
& communication with staff and peers \\
& building networks - study groups \\
& learning resources \\
& support for students with difficulties/disabilities \\
\hline \multirow{3}{*}{ Support \& guidance } & academic integrity \\
& plagiarism \\
& referencing \\
\hline
\end{tabular}

74 Journal of Higher Education Theory and Practice Vol. 21(13) 2021 


\begin{tabular}{|l|l|}
\hline Skill categories & Services for students \\
\hline \multirow{3}{*}{ Digital skills } & webinars \\
& $\begin{array}{l}\text { distance learning } \\
\text { online resources } \\
\text { online exams preparation } \\
\text { support for VLE/LMS }\end{array}$ \\
\hline
\end{tabular}

\section{Academic Skills}

CTLs teach students how to use effective study strategies such as time management, tackling procrastination, efficient text reading and studying, note-taking skills, text skimming and scanning for meaning, handling large amounts of information and proofreading. They also teach students how to focus on study and be more productive, how to be more motivated and set the right priorities. Moreover students can learn about resources management, problem-solving strategies and critical thinking, how to write academic assignments, how to develop reasoning and arguments. They are offered support in maths and statistics, in studying for midterm or final exams and self-assessment methods.

\section{Support and Guidance}

Students are offered support for moving to a new environment and living in the University campus. They are also given individual support and guidance or study assistance as needed. They learn how to communicate efficiently with fellow students and academic staff, how to complete student questionnaires, how to participate in learning networks and study groups, how to access learning resources. In addition CTLs offer learning counseling, teach communication and creative skills, help with managing stress and coping with it, offer support for students with learning difficulties, specialties or disabilities.

\section{Academic Behavior}

Students are offered support for achieving academic integrity, for recognizing and avoiding plagiarism, for using correct references and using academically accepted language and expressions.

\section{Digital Skills}

CTLs organize webinars, offer distance learning experiences, online study resources and digital information retrieval skills. They offer students online exam preparation and often support for virtual learning environments / learning management systems (VLE / LMS) and distance learning situations.

\section{CONCLUSION}

CTLs were established to contribute in providing quality assurance concerning teaching and learning in higher education institutes. Academics are considered as the main and "most important learning resource" (EAQAHE, 2005:17) available to students and therefore a call for professionalizing higher education teaching is raised (European Commission, 2013; Pleschová et al., 2012). A student-centered culture has been emerging in the framework of these academic learning communities, in order for good practices, experiences, and concerns to be shared among academic teachers along with their ability to create and understand how to facilitate students' learning in digital environments and distance learning which are crucial after COVID-19 pandemic (UNESCO, 2020).

The aim of this study was to examine the main areas where CTLs offer services, courses, and support for teaching staff and students. Regarding the distribution of CTLs of the top 100 universities, it is rather not surprising that the vast majority of them are situated in the US, Canada, Australia, and Europe, following the relevant ranking of universities. It is worth mentioning that the majority of them do not restrict their fields of activities to teaching staff (faculty members, post-graduate students), extending them to students and research staff as well.

Concerning the thematic areas of the services provided, most of them offer training programs and consultation/support, while some other interesting areas of activities include the production of educational 
materials, events organizing, and support for the use of ICT. As for the content of the courses provided to teaching staff, we can conclude that the main sectors are those of course design, teaching strategies, and feedback and assessment.

The relevant literature review revealed that students face problems in relation to the pace of study, academic and study skills, some psychosocial factors and active participation in learning and self-directed learning. As a result, the main sectors of activities CTLs try to offer their students in order to help learning and enhance academic success, include academic skills (studying strategies and productivity enhancement), acceptable academic behavior, digital skills and general support and guidance.

\section{ACKNOWLEDGEMENT}

A first version of a part of this article has been already presented at the HEAD 2021 Conference (Asimakopoulos, Karalis, \& Kedraka, 2021).

\section{REFERENCES}

Adebayo, F.A. (2015). Time Management and Students Academic Performance in Higher Institutions, Nigeria - A Case Study of Ekiti State. International Research in Education, 3(2), 1-12. http://dx.doi.org/10.5296/ire.v3i2.7126

Asimakopoulos, G., Karalis, T., \& Kedraka, K. (2021). Students learning can be enhanced via Centres of Teaching and Learning in Higher Education. In 7th International Conference on Higher Education Advances, 22-23 June 2021 (pp. 711-718). Universitat Politecnica de Valencia.

Atik, G., \& Yalçin, I. (2010). Counseling needs of educational sciences students at the Ankara University. Procedia Social and Behavioral Sciences, 2, 1520-1526.

Blankstein, M., Wolff-Eisenberg, C., \& Braddlee. (2019, September 30). Student Needs Are Academic Needs: Community College Libraries and Academic Support for Student Success. https://doi.org/10.18665/sr.311913

Brooker, A., Brooker, S., \& Lawrence, J. (2017, March). First year students' perceptions of their difficulties. Student Success, 8(1), 49-62. https://doi.org/10.1016/j.sbspro.2010.03.228

Cooke, R., Bewick, B.M., Barkham, M., Bradley, M., \& Audin, K. (2006). Measuring, monitoring and managing the psychological well-being of first year university students. British Journal of Guidance \& Counselling, 34(4), 505-517. https://doi.org/10.1080/03069880600942624

Dagdag, J., Cuizon, H., \& Bete, A. (2019). College Students' Problems and Their Link to Academic Performance: Basis for Needs- driven Student Programs. Journal of Research, Policy \& Practice of Teachers \& Teacher Education, 9, 54-65. https://doi.org/10.37134/jrpptte.vo19.no2.5.2019

Dalli, M. (2014). The university students' time management skills in terms of their academic life satisfaction and academic achievement levels. Educational Research and Reviews, 9(20), 10901096.

Dietsche, P. (2012). Use of Campus Support Services by Ontario College Students. Canadian Journal of Higher Education - Revue Canadienne d' Enseignement Supérier, 42(3), 65-92.

European Association for Quality Assurance in Higher Education (EAQAHE). (2015). Standards and Guidelines for Quality Assurance in the European Higher Education Area (ESG). Brussels, Belgium.

European Commission. (2013). High Level Group on the Modernization of Higher Education. Retrieved from http://europa.eu/rapid/press-release_IP-13-554_el.htm

Fook, C.Y., \& Sidhu, G.K. (2015). Investigating Learning Challenges Faced by Students in Higher Education. Procedia - Social and Behavioral Sciences, 186, 604-612. ISSN 1877-0428. https://doi.org/10.1016/j.sbspro.2015.04.001

Fry, H., Ketteridge, S., \& Marshall, S. (2009). A Handbook for Learning and Teaching in Higher Education: Enhancing Academic Practice (3rd ed.). London: Routledge.

76 Journal of Higher Education Theory and Practice Vol. 21(13) 2021 
Giovazolias, T., Leontopoulou, S., \& Triliva, S. (2010). Assessment of Greek University Students' Counseling Needs and Attitudes: An Exploratory Study. Int J Adv Counseling, 32, 101-116.

Griffin, R., MacKewn, A., Moser, E., \& VanVuren, K.W. (2012). Do Learning And Study Skills Affect Academic Performance? - An Empirical Investigation. Contemporary Issues In Education Research, 5(2), 109-116.

Hassanbeigi, A. Askari, J., Nakhjavani, M., Shirkhoda, S., Barzegar, K., Mozayyan, M.R., \& Fallahzaden, H. (2011). The relationship between study skills and academic performance of university students. Procedia- Social and Behavioral Sciences, 30, 1416-1424.

Hurtado, S., \& Sork, V.L. (2015, December). Enhancing student success and building inclusive classrooms at UCLA: Report to the Executive Vice Chancellor and Provost. Retrieved August 10, 2021, from http://wscuc.ucla.edu/wp-content/uploads/2019/01/C5_16_Report_Enhancing_ Student_Success-Building_Inclusive_Classrooms_at_UCLA_December_2015.pdf

Kedraka, K., \& Rotidi, G. (2017). University Pedagogy: A New Culture Is Emerging in Greek Higher Education. International Journal of Higher Education, 6(3), 147-153.

Klemenčič, M., Pupinis, M., \& Kirdulytè, G. (2020). Mapping and analysis of student-centred learning and teaching practices: Usable knowledge to support more inclusive, high-quality higher education. NESET report, Luxembourg: Publications Office of the European Union. https://doi.org/10.2766/67668

Krumrei-Mancuso, E.J., Newton, F.B., Kim, E., \& Wilcox, D. (2013, May-June). Psychosocial Factors Predicting First-Year College Student Success. Journal of College Student Development, 54(3), 247-266. https://doi.org/10.1353/csd.2013.0034

Malek, A.S. (2014). Common Issues University Students Face: Problems and Solutions. International Journal of Liberal Arts and Social Science, 2(2).

McDowell, L., Sambell, K., Bazin, V., Penlington, R., Wakelin, D., Dickes, H., \& Smailes, J. (2007). Assessment for Learning: Current Practice Exemplars from the Centre for Excellence in Teaching and Learning. REAP International Online Conference on Assessment Design for Learner Responsibility, $29^{\text {th }}-31^{\text {st }}$ May. Retrieved August 10, 2021, from https://bit.ly/2SgwwCV

Naqvi, S., Chikwa, G., Menon, U., \& Kharusi, D.A. (2018). Study Skills Assessment among Undergraduate Students at a Private University College in Oman. Mediterranean Journal of Social Sciences, 9(2), 139-147.

Pleschová, G., Simon, E., Quinlan, K.M., Murphy, J., \& Roxa, T. (2012). The professionalisation of academics as teachers in higher education. Science Position Paper. Standing Committee for the Social Sciences.

Raikou, N., \& Karalis, T. (2011). Exploring the potential of Transformative Learning in Higher Education: The development of students' critical thinking through aesthetic experience. 9th International Conference on Transformative Learning. Athens, 28-29 May 2011. In M. AlhadeffJones \& A. Kokkos (Eds.), Transformative Learning in Time of Crisis: Individual and Collective Challenges (pp. 261-267). Athens: Columbia University and Hellenic Open University.

Sahin, M.C. (2009). Instructional design principles for $21^{\text {st }}$ century learning skills. Procedia Social and Behavioral Sciences, 1, 1464-1468. http://doi.org/10.1016/j.sbspro.2009.01.258

Stelnicki, A., Nordstokke, D., \& Saklofske, D. (2015). Who Is the Successful University Student? An Analysis of Personal Resources. Canadian Journal of Higher Education - Revue Canadienne d' Enseignement Supérier, 45(2), 214-228.

Tanga, M., \& Maphosa, C. (2018). Academic hurdles facing undergraduate students at one South African University. Research in Higher Education Journal, 35, 1-15.

Tekkol, I.A., \& Demirel, M. (2018). An Investigation of Self-Directed Learning Skills of Undergraduate Students. Frontiers on Psychology, 9(2324), 1-14. https://doi.org/10.3389/fpsyg.2018.02324

TOP UNIVERSITIES. (2020, June 9). QS World University Rankings 2020. Retrieved August 10, 2021, from https://www.topuniversities.com/university-rankings/world-university-rankings/2020 
TOP UNIVERSITIES. (2020, June 9). The World's Top 100 Universities. Retrieved August 10, 2021, from https://www.topuniversities.com/student-info/choosing-university/worlds-top-100universities

Trueman, M., \& Hartley, J. (1996). A comparison between the time-management skills and academic performance of mature and traditional-entry university students. High Educ, 32, 199-215. https://doi.org/10.1007/BF00138396

UNESCO. (2020). COVID-19 and higher education: Today and tomorrow. Retrieved from http://www.iesalc.unesco.org/en/wp-content/uploads/2020/04/COVID-19-EN-090420-2.pdf

Wells, G., \& Edwards, A. (2013). Pedagogy in Higher Education: A Cultural Historical Approach. Cambridge University Press. 